\title{
USE OF ANAEROBIC CECAL MICROFLORA, LACTOSE AND ACETIC ACID FOR THE PROTECTION OF BROILER CHICKS AGAINST EXPERIMENTAL INFECTION WITH SALMONELLA TYPHIMURIUM AND SALMONELLA ENTERITIDIS
}

\author{
Raphael Lucio Andreatti Filho ${ }^{* *}$; Edir Nepomuceno da Silva ${ }^{2}$; Aldemir Reginato Ribeiro ${ }^{1}$; Nancy Kondo ${ }^{1}$; \\ Paulo Roberto Curi ${ }^{3}$
}

\begin{abstract}
${ }^{1}$ Departamento de Clínica Veterinária, ${ }^{3}$ Departamento de Melhoramento e Nutrição Animal, Faculdade de Medicina Veterinária e Zootecnia, Universidade Estadual Paulista, Botucatu, SP, Brasil. ${ }^{2}$ Departamento de Tecnologia de Alimentos, Faculdade de Engenharia de Alimentos, Universidade Estadual de Campinas, Campinas, SP, Brasil
\end{abstract}

Submitted: May 12, 1998; Returned to authors for corrections: September 24, 1998; April 20, 2000

\begin{abstract}
The effects of treatment with anaerobic cecal microflora (ACM) and/or lactose and/or acetic acid on systemic and digestive tract of broiler chicks infection with Salmonella Typhimurium and $S$. Enteritidis were studied. ACM was used without previous bacterial identification. Treatment with ACM contributed to the resistance of broiler chicks to infection with Salmonella spp. The infections were more persistent in the cecum, rectum and crops in decreasing order of intensity. The infections were also self-limiting since treated and control lots presented similar infection rates at the end of the experiments. Alone or in combination with lactose, ACM reduced the colonization of the digestive tract of broiler chicks by $S$. Typhimurium and $S$. Enteritidis. The effect of the combination of ACM with lactose or acetic acid was not potentiated in terms of reduction of fecal excretion of Salmonella spp. Treatment with ACM reduced the amount of $S$. Typhimurium and $S$. Enteritidis in the feces. Alone or in combination with lactose, ACM reduced the cecal $\mathrm{pH}$ in treated birds. $S$. Enteritidis was much more invasive than $S$. Typhimurium and the use of ACM alone was more effective on the reduction of systemic infection. An explanation for the process of prevention of intestinal colonization with Salmonella spp. probably resides in the interrelationship of physiological, microbiological and immunological phenomena, as well as the variation in cecal $\mathrm{pH}$.
\end{abstract}

Key words: Salmonella Typhimurium, $S$. Enteritidis, anaerobic cecal microflora, competitive exclusion, lactose, acetic acid, broiler chicks

\section{INTRODUCTION}

The incidence of food poisoning by Salmonella spp. has been increasing in various parts of the world despite the technological advances in food production and the adoption of better hygienic measures. Foods of animal origin continue to be the major factors responsible, among them chicken meat, eggs and derivatives. Contaminated chickens become intestinal carriers, eliminating the microorganism through the feces for long periods of time. Contaminated chickens thus end up introducing the bacteria in slaughterhouses (2).

Defined or undefined anaerobic bacterial cultures of avian origin, as well as various carbohydrates and organic acids have been used experimentally and commercially for the prevention of salmonellosis in broiler chickens. The undefined forms of culture have shown to give better protection against Salmonella spp. than defined cultures $(13,14,27)$. The normal intestinal microbiota of poultry consists of Bacillus, Bacteroides, Bifidobacterium, Citrobacter, Clostridium, Enterococcus, Escherichia, Eubacterium, Fusobacterium, Lactobacillus,

\footnotetext{
* Corresponding author. Mailing address: Departamento de Clínica Veterinária, Faculdade de Medicina Veterinária e Zootecnia, UNESP, Caixa Postal 560, CEP 18618-000, Botucatu, SP, Brasil. Email: andreatti@laser.com.br.
} 
Lactococcus, Pediococcus, Peptostreptococcus, Propionibacterium, Ruminococcus, Streptococcus, among others $(10,14,16,24)$. Several bacterial genera isolated from these cultures have been shown to have a protective effect on chickens against salmonellosis $(14,24)$.

The protective action of these cultures in the intestine of chickens is attributed to bacterial competition for adherence sites, a process (phenomenon) called "competitive exclusion", and to the production of short-chain volatile organic acids starting from lactose, for example, with a reduction in cecal $\mathrm{pH}(19,28,32)$.

The understanding of the mechanism of action of this microflora, of its quantitative and qualitative composition, of how it can be reproduced in vitro, and of how its action can be maintained in vivo is still incomplete.

The objective of the present study was to evaluate the use of anaerobic cecal microflora, lactose and acetic acid separately or in combination for the protection of broiler chicks against experimental infection with Salmonella Typhimurium and Salmonella Enteritidis.

\section{MATERIALS AND METHODS}

Chickens. Commercial one-day-old broiler chicks (Hubbard) were used, identified and kept in wire cages in a heated environment with free access to unmedicated commercial feed and water.

Bacterial strains and challenge. A $S$. Typhimurium strain and a $S$. Enteritidis phagetype 28 strain were used. They were isolated from the cecum and liver, respectively, of broiler breeders, and selected for resistance to nalidixic-acid $\left(\mathrm{Nar}^{\mathrm{R}}\right)$ by successive cultures on brilliant green agar (BGA-Difco) containing $100 \mu$ g nalidixic-acid $(\mathrm{Na}) / \mathrm{ml}$ medium $(2,3,4,30)$. Strain cultures in brain heart infusion (BHI-Difco) incubated at $40^{\circ} \mathrm{C}$ for 12 hours were used as inocula. All groups received $10^{9}$ colony-forming units (CFU) of $S$. Typhimurium and $S$. Enteritidis/chick, except for the control group which was challenged with $10^{8} \mathrm{CFU}$ of $S$. Enteritidis/chick. The number of $\mathrm{CFU}$ in the inocula and in the liver macerates was determined by plating $0.1 \mathrm{ml}$ of the suspensions and of their respective decimals dilutions onto sterile phosphate-buffered saline (PBS), $\mathrm{pH} 7.2$, in BGA supplemented with $100 \mu \mathrm{g} \mathrm{Na} / \mathrm{ml}(2,3,4,30)$. The chicks were challenged by intraesophageal inoculation of $0.5 \mathrm{ml}$ of the bacterial suspension with the aid of $1 \mathrm{ml}$ pipette on the third day of age.

Preparation of a anaerobic cecal microflora (ACM). ACM was obtained by culturing the pooled macerates of three ceca for 24 hours at $40^{\circ} \mathrm{C}$ in fluid thioglycollate medium (FTMDifco) in an anaerobiosis jar containing an anaerobic system (Difco). For this proceduring, three 43 weeks old broiler breeders (Arbor Acres) were slaughtered and their ceca were separated at the ileocecal junction, collected, wrapped in aluminum foil, taken to the laboratory and frozen for a period not exceeding 48 hours until the time of use. This procedure was carried out three times in order to obtain five ACM lots. These ACM lots were studied for the presence of Salmonella spp. according to Mallinson and Snoeyenbos $(2,17)$.

Treatments and ACM inocula. The treatments were carried out for five consecutive days starting on the first day of age. Lactose and acetic acid P.A. at 7 and $0.9 \%$ concentration, respectively, were administered in drinking water and the ACM was inoculated intraesophageally once a day with the aid of a graduated $1 \mathrm{ml}$ pipette with $0.5 \mathrm{ml}$ of the culture containing $10^{8}$ $\mathrm{CFU}$, as determined by plating $0.1 \mathrm{ml}$ of the FTM suspensions and their respective decimal dilutions in PBS onto thioglycollate agar in duplicate (FTM plus $1.5 \%$ bacto agar-Difco). These plates were then incubated for 24 hours at $40^{\circ} \mathrm{C}$, in an anaerobiosis jar containing an anaerobic system $(2,3,4)$.

Experimental design. For each serovar of Salmonella spp., five groups of 20 chicks were used. At 24, 96, 240 and 432 hours after challenge, three chicks were removed from each group for weighing, slaughtering and sampling of material. The liver was aseptically removed, individually triturated and suspended in $20 \mathrm{ml}$ PBS. This suspension and its decimal dilutions were used for CFU counts by plating $0.1 \mathrm{ml}$ of the preparation onto BGA-containing $\mathrm{Na}$ in duplicate, followed by incubation for 24 hours at $40^{\circ} \mathrm{C}$. Colonization of the digestive tract was determined by direct culture of the crop, cecum and rectum with the aid of a swab immersed in BGA-Na $(1,2,3,4$, 29 ) and scored for intensity of bacterial growth as follows: 0.1 to 1 for growth of 1 to $10 \mathrm{CFU}, 1.1$ to 2 for 11 to $50 \mathrm{CFU}, 2.1$ to 3 for 51 to $100 \mathrm{CFU}$, and 4 for more than $100 \mathrm{CFU}$. In parallel to the quantification of the cecal colonization, two fragments of $0.3 \mathrm{~g}$ of the cecum were placed in a test tube containing $2.4 \mathrm{ml}$ distilled water, $\mathrm{pH}$ 7.0. After shaking, the content was submitted to $\mathrm{pH}$ determination with a $\mathrm{pH}-$ meter (32). Bacterial excretion in the feces was quantified in samples collected on aluminum foil placed under the cages during the night preceding collection. Ten grams of feces from each group were suspended in $100 \mathrm{ml}$ PBS and their respective decimal dilutions were used for the determination of $\mathrm{CFU} / \mathrm{g}$ plating $0.1 \mathrm{ml}$ BGA-containing $\mathrm{Na}$ in duplicate and culturing it for 24 hours at $40^{\circ} \mathrm{C}(1,2,3,4)$.

Statistical analysis. In view of the fact that the feces of several chicks were pooled on each of the four collection days, comparison of bacterial data in the various treatments was performed using the nonparametric Friedman test, with the day of data collection being considered as a block. Data concerning cecal $\mathrm{pH}$ were analyzed by analysis of variance for fully randomized experiments in order to determine the effects of treatment $x$ time interaction, of treatment and of time. Because of the nature of the variables studied which represent evaluations based on scores (colonization of the digestive tract) or CFU counts (Salmonella quantification in the liver), we used a nonparametric analysis for fully randomized experiments in order to determine the effects of treatment $\mathrm{x}$ time interaction, of 
treatment and of time individually. In all analyses, the level of significance was set at $\mathrm{p}<0.05(31)$.

\section{RESULTS}

Colonization of the digestive tract and fecal excretion. The use of ACM alone or in combination with lactose significantly reduced the colonization of the digestive tract of the chicks by both $S$. Typhimurium and $S$. Enteritidis (Tables 1 and 2). The use of ACM in combination with acetic acid only determined reduction in the cecum and rectum. Colonization of the digestive tract was more persistent in the cecum, followed by the rectum and crop, in this order, regardless of the Salmonella serotype or of the treatment used (Tables 1 and 2).

The use of ACM in combination with lactose or ACM in combination with acetic acid, in contrast to the use of ACM alone, did not reduce fecal excretion of $S$. Typhimurium. Only treatment with ACM separately caused a significant reduction of bacteria in the feces, when compared to the control group
(Table 2). However, when $S$. Enteritidis was used to challenge the chicks, only the treatment with ACM alone or in combination with acetic acid caused a significant reduction of bacteria in feces. The combination of ACM with lactose did not reduce the amount of $S$. Enteritidis in the feces (Table 1).

Salmonella quantification in the liver. Bacterial quantification in the liver was the indicator of bacteremia caused by the Salmonella serotypes used (Table 3 ). $S$. Typhimurium was detected only in the control group during a period of 24 hours after challenge. $S$. Enteritidis was detected in the liver 24, 96 and 240 hours after challenge. ACM alone was more effective in preventing bacteremia than the other treatments (Table 3 ).

During the last period of analysis ( 432 hours after challenge) the infections of the digestive tract and of the liver showed similar indices in terms of the challenging serotypes, regardless of the treatment used (Tables 1,2 and 3).

Cecal pH. The use of ACM alone contributed to a reduction in the cecal $\mathrm{pH}$ of the chicks 24 hours after challenge with both serotypes and 96 hours after challenge with $S$. Enteritidis. The

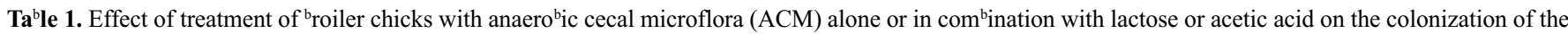
digestive tract ${ }^{\mathrm{b}} \mathrm{y} S$. Enteritidis and its fecal excretion.

\begin{tabular}{|c|c|c|c|c|c|c|c|c|c|c|c|c|c|}
\hline \multirow{3}{*}{ Treatments } & \multicolumn{12}{|c|}{ Colonization at different time (hours) after challenge with $S$. Enteritidis* } & \multirow{3}{*}{$\begin{array}{c}\text { Fecal } \\
\text { Excretion** }\end{array}$} \\
\hline & \multicolumn{4}{|c|}{ Crop } & \multicolumn{4}{|c|}{ Cecum } & \multicolumn{4}{|c|}{ Rectum } & \\
\hline & 24 & 96 & 240 & 432 & 24 & 96 & 240 & 432 & 24 & 96 & 240 & 432 & \\
\hline Control & $0.3^{\mathrm{Ab}}$ & $1.3^{\mathrm{Bc}}$ & $3.0^{\mathrm{C}} \mathrm{d}$ & $0^{\mathrm{Aa}}$ & $4.0^{\mathrm{Bb}}$ & $4.0^{\mathrm{Bb}}$ & $4.0^{\mathrm{Bb}}$ & $0.3^{\mathrm{Aa}}$ & $3.0^{\mathrm{Cb}}$ & $3.3^{\mathrm{Cb}}$ & $3.0^{\mathrm{Bb}}$ & $0.3^{\mathrm{Aa}}$ & $6.5^{\mathrm{C}}$ \\
\hline $\mathrm{ACM}$ & $0.6^{\mathrm{Ab}}$ & $1.6^{\mathrm{Bb}}$ & $0^{\mathrm{Aa}}$ & $0^{\mathrm{Aa}}$ & $0.3^{\mathrm{Aa}}$ & $2.3^{\mathrm{Ab}}$ & $0.6^{\mathrm{Aa}}$ & $0.6^{\mathrm{ABa}}$ & $0^{\mathrm{Aa}}$ & $1.3^{\mathrm{Bb}}$ & $0^{\mathrm{Aa}}$ & $0^{\mathrm{Aa}}$ & $2.9^{\mathrm{A}}$ \\
\hline $\mathrm{ACM}+$ Lactose & $0.3^{\mathrm{Ab}}$ & $0^{\mathrm{Aa}}$ & $0.3^{\mathrm{ABb}}$ & $0^{\mathrm{Aa}}$ & $4.0^{\mathrm{B}} \mathrm{d}$ & $2.0^{\mathrm{Ac}}$ & $1.0^{\mathrm{Ab}}$ & $0^{\mathrm{Aa}}$ & $3.3^{\mathrm{Cb}}$ & $0.3^{\mathrm{Aa}}$ & $0.3^{\text {Aa }}$ & $0^{\mathrm{Aa}}$ & $5.5^{\mathrm{BC}}$ \\
\hline $\mathrm{ACM}+$ Acetic acid & $0.6^{\mathrm{Ab}}$ & $0.3^{\mathrm{Aa}}$ & $1.3^{\mathrm{Bab}}$ & $0.3^{\mathrm{Aa}}$ & $4.0^{\mathrm{Bc}}$ & $1.6^{\mathrm{Ab}}$ & $0.3^{\mathrm{Aa}}$ & $0^{\mathrm{Aa}}$ & $1.0^{\mathrm{Bb}}$ & $1.3^{\mathrm{Bb}}$ & $0.3^{\mathrm{Aa}}$ & $0.3^{\mathrm{Aa}}$ & $4.2^{\mathrm{AB}}$ \\
\hline
\end{tabular}

* Mean colonization scores for three birds: "0.1 to 1 " for 1 to 10 colony-forming units (CFU); " 1.1 to 2 " for 11 to $50 \mathrm{CFU}$; "2.1 to 3 " for 51 to $100 \mathrm{CFU}$; and " 4 ", $\mathrm{a}^{\mathrm{b}}$ ove $100 \mathrm{CFU}$.

** Mean results for the four periods of analysis, reported as CFU/gram feces $\left(\log _{10}\right)$.

Different capital letters in the column indicate differences between treatments at each time; different lower case letters on the line indicate differences between times within each treatment $(\mathrm{p}<0.05)$

Table 2. Effect of treatment of broiler chicks with anaerobic cecal microflora (ACM) alone or in combination with lactose or acetic acid on the colonization of the digestive tract by $S$. Typhimurium and its fecal excretion.

\begin{tabular}{|c|c|c|c|c|c|c|c|c|c|c|c|c|c|}
\hline \multirow{3}{*}{ Treatments } & \multicolumn{12}{|c|}{ Colonization at different time (hours) after challenge with $S$. Typhimurium* } & \multirow{3}{*}{$\begin{array}{c}\text { Fecal } \\
\text { Excretion** }\end{array}$} \\
\hline & \multicolumn{4}{|c|}{ Crop } & \multicolumn{4}{|c|}{ Cecum } & \multicolumn{4}{|c|}{ Rectum } & \\
\hline & 24 & 96 & 240 & 432 & 24 & 96 & 240 & 432 & 24 & 96 & 240 & 432 & \\
\hline $\mathrm{ACM}$ & $0^{\mathrm{Aa}}$ & $0^{\mathrm{Aa}}$ & $0^{\mathrm{Aa}}$ & $0^{\mathrm{Aa}}$ & $1.0^{\mathrm{Bb}}$ & $0^{\text {Aa }}$ & $0^{\mathrm{Aa}}$ & $0^{\mathrm{Aa}}$ & $0.3^{\mathrm{Ab}}$ & $0^{\mathrm{Aa}}$ & $0^{\mathrm{Aa}}$ & $0^{\mathrm{Aa}}$ & $1.5^{\mathrm{A}}$ \\
\hline $\mathrm{ACM}+$ Lactose & $0^{\mathrm{Aa}}$ & $0^{\text {Aa }}$ & $0.3^{\mathrm{Aa}}$ & $0^{\mathrm{Aa}}$ & $0^{\mathrm{Aa}}$ & $0^{\mathrm{Aa}}$ & $0^{\mathrm{Aa}}$ & $0^{\mathrm{Aa}}$ & $1.0^{\mathrm{Bb}}$ & $0^{\mathrm{Aa}}$ & $0^{\mathrm{Aa}}$ & $0^{\mathrm{Aa}}$ & $3.1^{\mathrm{AB}}$ \\
\hline
\end{tabular}

* Mean colonization scores for three birds: "0.1 to 1" for 1 to 10 colony-forming units (CFU); " 1.1 to 2 " for 11 to 50 CFU; " 2.1 to 3 " for 51 to 100 CFU; and " 4 ", above 100 CFU.

** Mean results for the four periods of analysis, reported as CFU/gram feces $\left(\log _{10}\right)$.

Different capital letters in the column indicate differences between treatments at each time; different lower case letters on the line indicate differences between times within each treatment $(\mathrm{p}<0.05)$. 
Table 3. Effect of treatment of broiler chicks with anaerobic cecal microflora $(\mathrm{ACM})$ alone or in combination with lactose or acetic acid on hepatic infection by $S$. Enteritidis*.

\begin{tabular}{ccccc}
\hline & \multicolumn{4}{c}{ Time (hours) after challenge with $S$. Enteritidis } \\
\cline { 2 - 5 } Treatments & 24 & 96 & 240 & 432 \\
\hline Control & $5.5^{\mathrm{Bc}}$ & $3.7^{\mathrm{Bb}}$ & $3.8^{\mathrm{Bb}}$ & $0^{\mathrm{Aa}}$ \\
ACM & $3.6^{\mathrm{Ac}}$ & $2.3^{\mathrm{Ab}}$ & $0^{\mathrm{Aa}}$ & $0^{\mathrm{Aa}}$ \\
$\mathrm{ACM}+$ Lactose & $4.1^{\mathrm{Bc}}$ & $3.6^{\mathrm{Bb}}$ & $1.1^{\mathrm{Aa}}$ & $0^{\mathrm{Aa}}$ \\
ACM + Acetic acid & $3.6^{\mathrm{Ab}}$ & $3.8^{\mathrm{Bb}}$ & $1.1^{\mathrm{Aa}}$ & $0^{\mathrm{Aa}}$ \\
\hline
\end{tabular}

* Results are reported as decimal logarithm of mean colony-forming units $(\mathrm{CFU}) /$ liver for three birds

Different capital letters in the column indicate differences between treatments at each time; different lower case letters on the line indicate differences between times within each treatment $(\mathrm{p}<0.05)$

combination of ACM and lactose reduced the cecal $\mathrm{pH}$ of the birds at 24 and 96 hours after challenge with $S$. Enteritidis. The combination of ACM and acetic acid did not cause a significant change in cecal $\mathrm{pH}$. When the challenge was with $S$. Typhimurium, only ACM alone reduced the cecal $\mathrm{pH}$ of the chicks 24 hours after challenge (Table 4).

\section{DISCUSSION AND CONCLUSIONS}

Colonization by $S$. Typhimurium and $S$. Enteritidis in the different segments of the digestive tract and in the liver of control chicks showed that the infection of chickens with paratyphoid Salmonella was self-limiting, as previously observed by Barrow et al. (1988), since the amount of Salmonella spp. during the last period of analysis was always similar regardless of the treatments used. However, the bacterial reduction provided by the use of ACM seems to be fundamental to decrease the spread of the paratyphoid infection, because the excretion through feces occurs frequently and is extremely common in chickens.

The present data demonstrate that infection of the digestive tract of chickens with paratyphoid Salmonella is more effective and persistent in the cecum, rectum and crop, in this order, which are important sites of paratyphoid infections in chickens $(2,3$, $4,5,11)$. The cecum is the site of highest colonization by Salmonella spp., as well as by other pathogenic species of the family Enterobacteriaceae, such as Escherichia coli, compared to other sites in the digestive tract (1) and its colonization is used as a parameter for the evaluation of the efficacy of treatment against salmonellosis $(2,3,4,8,18,19)$. This characteristic is related to the presence of specific receptors in the organ, to the physiology of cecal peristalsis causing a longer time of permanence of the food bolus and to $\mathrm{pH}$, among other factors $(8,9,18,32)$.

Lactose at concentrations of 2.5 to $7.0 \%$ has been the most frequently used carbohydrate in studies aiming at the reduction of Salmonella spp. in the intestine of chickens (2, 4, 8, 9, 18, $19,22,23,28,32)$. Its effect is due to the fact that lactose is not fully digested by chickens because of their lactase deficiency, with the carbohydrate reaching the cecum in practically intact form, and being fermented there by the cecal microflora which produces antagonistic substances against Salmonella spp. (15). The control of infection by Salmonella spp. in chickens can also be made through the treatment with organic acids, as acetic, propionic, butyric, lactic, succinic, formic and fumaric in the feed $(6,7,12,20)$. The action of the organic acids was not yet totally identified, seeming related with the bacterial cell as antimicrobial agent $(6,7)$. Molecules of these organic acids may passively penetrate bacterial cells, dissociating into protons and anions, depending on internal $\mathrm{pH}$. Cytoplasm acidification apparently is one of the causes of inhibition of bacterial growth, even causing cell death $(7,26)$.

The effect of the use of carbohydrates and organic acids on the control of colonization and infection by Salmonella spp. in chickens seems to depend on the type of carbohydrate or organic acids, on the dose administered, on the route of administration, and on the inoculum of Salmonella spp. $(8,25)$. Organic acids are not effective against Salmonella spp. when added to dry feed. The antimicrobial effect only happens when the chicken ingests the feed and this is moisturized immediately (12). In these experiments, the synergistic effects of the combination of

Table 4. Effect of treatment with anaerobic cecal microflora (ACM) alone or in combination with lactose or acetic acid on the alteration of cecal pH in broiler chicks challenged with $S$. Typhimurium and $S$. Enteritidis*.

\begin{tabular}{|c|c|c|c|c|c|c|c|c|}
\hline \multirow[b]{2}{*}{ Treatments } & \multicolumn{4}{|c|}{ Time (hours) after challenge with $S$. Typhimurium } & \multicolumn{4}{|c|}{ Time (hours) after challenge with $S$. Enteritidis } \\
\hline & 24 & 96 & 240 & 432 & 24 & 96 & 240 & 432 \\
\hline Control & $6.6^{\mathrm{BCa}}$ & $6.6^{\mathrm{Aa}}$ & $6.6^{\mathrm{Aa}}$ & $6.6^{\mathrm{ABa}}$ & $7.0^{\mathrm{Ba}}$ & $6.6^{\mathrm{Ba}}$ & $6.4^{\mathrm{Aa}}$ & $6.7^{\mathrm{Aa}}$ \\
\hline $\mathrm{ACM}+$ Lactose & $5.8^{\mathrm{ABa}}$ & $6.0^{\mathrm{Aa}}$ & $7.1^{\mathrm{Ab}}$ & $6.7^{\mathrm{ABab}}$ & $5.3^{\mathrm{Aa}}$ & $5.5^{\mathrm{Aa}}$ & $7.0^{\mathrm{Ab}}$ & $7.1^{\mathrm{Ab}}$ \\
\hline $\mathrm{ACM}+$ Acetic acid & $7.0^{\mathrm{Ca}}$ & $6.8^{\mathrm{Aa}}$ & $7.0^{\mathrm{Aa}}$ & $7.3^{\mathrm{Ba}}$ & $7.3^{\mathrm{Ba}}$ & $6.8^{\mathrm{Ba}}$ & $6.8^{\mathrm{Aa}}$ & $7.0^{\mathrm{Aa}}$ \\
\hline
\end{tabular}

* Mean for three birds.

Different capital letters in the column indicate differences between treatments at each time; different lower case letters on the line indicate differences between times within each treatment $(\mathrm{p}<0.05)$. 
$\mathrm{ACM}$ and lactose and the combination of ACM and acetic acid did not reduce $S$. Typhimurium in the feces or cecal $\mathrm{pH}$. In the challenge with $S$. Enteritidis, the combination of ACM and acetic acid reduced the amount of the bacterium in the feces, as well as the cecal $\mathrm{pH}$. The combinations of ACM and lactose or acetic acid caused a lower colonization by $S$. Typhimurium and $S$. Enteritidis at different times after challenge in the crop, cecum and rectum.

The ACM used had no previous bacterial identification and undefined cultures have shown greater protection against Salmonella spp. than defined cultures $(2,3,4,13,14,24,27)$. When defined mixtures of chicken cecal bacteria were compared with cultures, the latter were found to be more protective in chickens challenged with $S$. Kedougou (21).

The cecal acidification observed in these experiments was also reported by other investigators and is to the production of organic acids resulting from carbohydrate fermentation by the intestinal microflora of chickens $(8,9,22,23,28,32)$. ACM alone or in combination with lactose reduced cecal $\mathrm{pH}$ during treatment after challenge with $S$. Typhimurium and $S$. Enteritidis. Although these treatments reduced cecal $\mathrm{pH}$, only ACM alone significantly reduced the amount of $S$. Typhimurium and $S$. Enteritidis in feces, indicating that the simple reduction of cecal $\mathrm{pH}$ may not reduce the amount of Salmonella spp.

The presence of Salmonella spp. in the liver and in various segments of the digestive tract showed that $S$. Enteritidis was more invasive than $S$. Typhimurium. It also showed that the use of ACM alone was the treatment that led to the greatest reduction of systemic infection.

The explanation for the process of prevention of intestinal colonization by Salmonella spp. is probably based on the interrelation of physiological, microbiological and immunological phenomena, as well as on the possible variation in cecal $\mathrm{pH}$.

\section{ACKNOWLEDGMENTS}

The authors are grateful to Fundação de Amparo à Pesquisa do Estado de São Paulo - FAPESP (Grant n 96/04637-6).

\section{RESUMO}

\section{Uso de microbiota cecal anaeróbia, lactose e ácido acético no controle da infecção experimental de frangos por Salmonella Typhimurium e Salmonella Enteritidis}

Estudaram-se os efeitos do tratamento de frangos com microbiota cecal anaeróbia (MCA) isolada ou associada à lactose ou ao ácido acético, sobre a infecção sistêmica e do trato digestivo de aves por Salmonella Typhimurium e $S$. Enteritidis. Foi usada MCA sem prévia identificação bacteriana. O tratamento com MCA contribuiu na resistência dos frangos à infecção por Salmonella spp. As infecções eram mais persistentes, em ordem, nos cecos, reto e inglúvio. As infecções também eram autolimitantes, pois lotes tratados e controles apresentaram índices semelhantes de infecção ao final dos experimentos. Isoladamente ou em associação com lactose, MCA reduziu a colonização do trato digestivo das aves por $S$. Typhimurium $e S$. Enteritidis. As associações MCA com lactose ou ácido acético, não tiveram seus efeitos potencializados na redução da excreção fecal. $\mathrm{O}$ tratamento com MCA diminuiu a quantidade de $S$. Typhimurium e $S$. Enteritidis nas fezes. O uso de MCA isolada ou associada com lactose contribuiu na redução do $\mathrm{pH}$ cecal das aves tratadas. A $S$. Enteritidis foi mais invasiva que a $S$. Typhimurium e, o uso da MCA isoladamente foi mais eficaz em evitar a infecção sistêmica que os outros tratamentos. A explicação do processo de prevenção da colonização intestinal por Salmonella spp. passa, provavelmente, pela inter-relação de fenômenos fisiológicos, microbiológicos e imunológicos, além da possível variação do $\mathrm{pH}$ cecal.

Palavras-chave: Salmonella Typhimurium, S. Enteritidis, microbiota cecal anaeróbia, exclusão competitiva, lactose, ácido acético, frango.

\section{REFERENCES}

1. Andreatti Filho, R.L.; Silva, E.N.; Balen, L. Efeito da via de inoculação na patogenicidade de amostras patogênica e apatogênica de Escherichia coli em galinha. Arq. Bras. Med. Vet. Zootec., 45: 475-486, 1993.

2. Andreatti Filho, R.L. Estudo do uso de carboidratos, ácidos orgânicos e microbiota cecal anaeróbia no controle da infecção experimental de aves por Salmonella Enteritidis $e$ Salmonella Typhimurium. São Paulo, 1997, 245p. (Ph.D. Thesis. Instituto de Ciências Biomédicas. USP).

3. Andreatti Filho, R.L.; Silva, E.N.; Curi, P.R. Ácidos orgânicos e microbiota cecal anaeróbia no controle da infecção experimental de frangos por Salmonella Typhimurium e Salmonella Enteritidis. Arq. Bras. Med. Vet. Zootec., 49: 661-672, 1997.

4. Andreatti Filho, R.L.; Silva, E.N.; Curi P.R. Control of experimental infection of broilers by Salmonella Enteritidis and $\mathrm{S}$. Typhimurium with the use of organic composites and anaerobic cecal microflora. International Symposium on Food-Borne Salmonella in Poultry, Baltimore, 1998, p.53.

5. Barrow, P.A.; Simpson, J.M.; Lovell, M.A. Intestinal colonisation in the chicken by food-poisoning Salmonella serotypes; microbial characteristics associated with faecal excretion. Avian Path., 17: 571-588, 1988.

6. Baskett, R.C.; Hentges, D.J. Shigella flexneri inhibition by acetic acid. Infect. Immun., 8: 91-97, 1973.

7. Cherrington, C.A.; Hinton, M.; Chopra, I. Effect of short-chain organic acids on macromolecular synthesis in Escherichia coli. J. Bacteriol., 68: 69-74, 1990.

8. Corrier, D.E.; Hinton Jr., A.; Ziprin, R.L.; Beier, R.C.; DeLoach, J.R. Effect of dietary lactose on cecal $\mathrm{pH}$, bacteriostatic volatile fatty acids and Salmonella typhimurium colonization of broiler chicks. Avian Dis., 34: 617-625, 1990.

9. Corrier, D.E.; Hinton Jr., A.; Ziprin, R.L.; DeLoach, J.R. Effect of dietary lactose on Salmonella colonization of market-age broiler chickens. Avian Dis., 34: 668-676, 1990.

10. Corrier, D.E.: Nisbet, D.J.; Scanlan, C.M.; Tellez, G.; Hargis, B.M.; DeLoach, J.R. Inhibition of Salmonella enteritidis cecal and organ colonization in leghorn chicks by a defined culture of cecal bacteria and dietary lactose. J. Food Prot., 57: 377-381, 1994. 
11. Hargis, B.M.; Caldwell, D.J.; Brewer, R.L.; Corrier, D.E.; DeLoach, J.R. Evaluation of the chicken crop as a source of Salmonella contamination for broiler carcasses. Poultry Sci., 74: 1548-1552, 1995.

12. Hinton, M., Linton, A.H. Control of Salmonella infections in broiler chickens by the acid treatment of their feed. Vet. Record, 123: 416-421, 1988.

13. Hinton, M.; Mead, G.C. Salmonella control in poultry: the need for the satisfactory evaluation of probiotics for this purpose. Lett. Appl. Microbiol.,13: 49-50, 1991.

14. Hudalt, S.; Bewa, H.; Bridonneau, C.; Raibaud, P. Efficiency of various bacterial suspensions derived from cecal floras of conventional chickens in reducing the population level of Salmonella typhimurium in gnotobiotic mice and chicken intestines. Can. J. Microbiol., 31: 832-838, 1985.

15. Hume, M.E.; Kubena, L.F.; Beier, R.C.; Hinton Jr., A.; Corrier, D.E.; DeLoach, J.R. Fermentation of $\left[{ }^{14} \mathrm{C}\right]$ lactose in broiler chicks by cecal anaerobes. Poultry Sci., 71: 1464-1470, 1992.

16. Impey, C.S.; Mead, G.C.; George, S.M. Competitive exclusion of Salmonella from the chick caecum using a defined mixture of bacterial isolates from the caecal microflora of an adult bird. J. Hyg., 89: 479-490, 1982.

17. Mallinson, E.T.; Snoeyenbos, G.H. Salmonellosis. In: Purchase, H.G. (ed). A laboratory manual for the isolation and identification of avian pathogens. Kennett Square, The American Association of Avian Pathologists, University of Pennsylvania, 1989, p.3-11.

18. McHan, F.; Cox, N.A.; Blankenship, L.C.; Bailey, J.S. In vitro attachment of Salmonella typhimurium to chick ceca exposed to selected carbohydrates. Avian Dis., 33: 340-344, 1989.

19. McHan, F.; Shotts, E.B.; Brown, J. Effect of feeding selected carbohydrates on the in vivo attachment of Salmonella typhimurium in chick ceca. Avian Dis., 35: 328-331, 1991.

20. McHan, F.; Shotts, E.B. Effect of short-chain fatty acids on the growth of Salmonella typhimurium in an in vitro system. Avian Dis., 37: 396-98, 1993.

21. Mead, G.C.; Impey, C.S. Control of Salmonella colonization in poultry flocks by defined gut-flora treatment. Proceeding International Symposium Salmonella, New Orleans, 1985, p.72-79.
22. Nisbet, D.J.; Corrier, D.E.; DeLoach, J.R Effect of mixed cecal microflora maintained in continuous culture and of dietary lactose on Salmonella typhimurium colonization in broiler chicks. Avian Dis., 37: 528-535, 1993.

23. Nisbet, D.J.; Corrier, D.E.; Scanlan, C.M.; Hollister, A.G.; Beier, R.C.; DeLoach, J.R. Effect of a defined continuous-flow derived bacterial culture and dietary lactose on Salmonella typhimurium colonization in broiler chickens. Avian Dis., 37: 1017-1025, 1993.

24. Oyarzabal, O.A.; Conner, D.E. In vitro fructooligosaccharide utilization and inhibition of Salmonella sp by selected bacteria. Poultry Sci., 74: 1418-1425, 1995.

25. Rambousek, M.J.; Iba, A.M.; Stachissini, A.V.M.; Berchieri, Jr., A. The effect of carbohydrate administration on experimental infection with Salmonella serotypes in chickens. Rev. Microbiol., 26: 32-36, 1995.

26. Salmond, C.V.; Kroll, R.G.; Booth, I.R. The effect of food preservatives on $\mathrm{pH}$ homeostasis in Escherichia coli. J. Gen. Microb., 130: 2843-2850, 1984.

27. Stavric, S.; D'Aoust, J.Y. Undefined and defined bacterial preparations for the competitive exclusion of Salmonella in poultry - a review. J. Food Prot., 56: 173-180, 1993.

28. Tellez, G.I.; Dean, C.E.; Corrier, D.E.; DeLoach, J.R.; Jaeger, L.; Hargis, B.M. Effect of dietary lactose on cecal morphology, $\mathrm{pH}$, organic acids and Salmonella enteritidis organ invasion in leghorn chicks. Poultry Sci., 72: 636-642, 1993

29. Weinack, O.M.; Snoeyenbos, G.H.; Smyser, C.F.; Soerjadi, A.S. Competitive exclusion of intestinal colonization of Escherichia coli in chicks. Avian Dis., 25: 696-705, 1981.

30. Weinack, O.M.; Snoeyenbos, G.H.; Smyser, C.F.; Soerjadi, A.S. Reciprocal competitive exclusion of Salmonella and Escherichia coli by native intestinal microflora of the chicken and turkey. Avian Dis., 26: 585-595, 1982.

31. Zar, J.H. Biostatistical Analisis. Englewood Cliffs, Prentice-Hall International Editions, 1984, 718p.

32. Ziprin, R.L.; Elissalde, M.H.; Hinton, Jr., A.; Spates, G.E.; Corrier, D.E.; Benoit, T.G.; DeLoach, J.R. Colonization control of lactose-fermenting Salmonella typhimurium in young broiler chickens by use of dietary lactose. Am. J. Vet. Res., 52: 833-837, 1991. 